University of California

Division of Agriculture and Natural Resources

http://anrcatalog.ucdavis.edu

Publication 8396 / November 2009

\title{
Fruit and Nut Varieties for Low-Elevation Sierra Foothills
}

JANINE HASEY, UC Farm Advisor, Sutter and Yuba Counties

The cultivation of fruit and nut trees at low elevations in the Sierra foothills presents many challenges. The pleasure and convenience of being able to pick tree-ripened fruit are the main factors that encourage foothill residents to overcome the obstacles. A simple knowledge of what varieties are better adapted to lower elevation foothill conditions and how to manage them can ease some of the home orchardist's frustrations. Over the course of a 14-year demonstration study (1992-2006) at the University of California Sierra Foothill Research and Extension Center in Browns Valley, Yuba County, a number of fruit and nut species and varieties emerged as better able to tolerate, or even thrive under, foothill soil and climate conditions. The study took place at 575 feet elevation. Of course, just as important as knowing which tree crops and varieties are best to plant are the knowledge of which ones to avoid planting, which rootstocks perform the best under those conditions, and which diseases and insects are most likely to cause problems.

\section{Variety and Rootstock Adaptation}

Researchers evaluated several standard varieties of apples, peaches, nectarines, apricots, plums, cherries, chestnuts, pecans, and walnuts, as well as some newer and antique varieties. The study included two to six replications of each variety and at least two trees each for different rootstock-variety combinations.

The low-elevation foothill test site has Auburn-Sobrante Complex gravelly soil at a 7 percent slope. When grown on these heavier, shallow foothill soils, even the most vigorous rootstocks and varieties tend to be smaller than they would be on a valley loam soil. The smaller tree size meant that our spacing for fruit trees $\left(18^{\prime} \times 18^{\prime}\right)$ and nut trees $\left(25^{\prime} \times 25^{\prime}\right)$ was too wide, and the trees never filled in the space. Your own trees should be planted at the closest spacing suggested for the particular variety and rootstock. Two keys to tree survival in high-rainfall years are to plant on slopes with good water drainage and to avoid swales where runoff water accumulates, since most rootstocks do not tolerate wet, saturated soils. Planting on a hillside or sloping terrain will also help prevent frost damage, as cold air will drain off to lower sites.

Trees should be trained as low as possible for ease of harvest and pest management, since homeowners and small commercial orchard operators do most of these operations by hand. To obtain properly sized fruit, you need to prune peaches, nectarines, plums, apricots, and apples every year and thin the fruit as it develops on the tree. Deer will browse on fruit and nut trees, so you will want to protect your orchard with an 8-foot deer 
fence if you're serious about growing a tree that yields fruit. Wild turkeys eat chestnuts and birds (crows and other species) eat or damage many crops just as they come ripe. Cherry, peach, pecan, and walnut trees should be netted to prevent bird damage. To control grasshoppers, which may be a sporadic problem, place an insecticidal bait on the orchard border. Gophers may also need to be controlled.

Table 1 lists specific fruit and nut tree varieties that are suited to low-elevation Sierra foothill sites. The table also shows the average bloom date for fruit trees and the basic spread of harvest dates for fruit and nut trees. Variety-specific pest problems or other special considerations appear in the right-hand column. Listed in table 2 are varieties and varietyrootstock combinations that performed poorly and are not recommended for low-elevation Sierra foothills.

Here are some general observations and recommendations on each fruit or nut tree species.

\section{Apples}

Apple varieties were grafted onto either M7 or M111 semi dwarf rootstock. In general, trees on M7 were poorly anchored, and many required staking because of their brittle root system. With two exceptions (table 2), all varieties performed better on M111. Most varieties produced adequate crops. Flavor is more of a personal preference. Codling moth presented an ongoing challenge, especially when trees were grown using organic methods. During the warm, wet springs of 2000 and 2005, fire blight disease caused extensive dieback in particularly susceptible varieties (table 1). You will need to manage for fire blight whenever environmental conditions are favorable for disease development.

\section{Apricots}

The original apricots in the study were grafted onto Marianna 2624 or apricot seedling (Royal Blenheim) rootstock. All six Blenheim (Royal) variety trees on Marianna 2624 rootstock were dead within seven years (table 2), whereas the Patterson variety continued to thrive on both Marianna 2624 and apricot seedling rootstocks. Marianna 2624 rootstock suckered profusely, however. Three newer apricot varieties on Citation, Lovell, and Nemaguard rootstocks were planted in 2000 and 2001 to replace the Blenheim (Royal) that had died. During the wet spring of 2006, all apricot trees on Nemaguard rootstock died from waterlogging, as did two apricot trees on Lovell rootstock. Surviving trees were growing on either Citation rootstock or Lovell rootstock on higher ground. Brown rot (Monilinia laxa or fructicola) destroyed the blossoms on all varieties in the wet spring of 2005.

\section{Peaches}

All peach trees were grown on Lovell peach rootstock. The life span of a peach tree is about 15 years; after thirteen years the Red Haven variety continued to be the most productive, although some trees had suffered sunburn damage and were declining. Overall, most varieties of peaches consistently yielded large crops of good-quality fruit. The main insect pest was peach twig borer. Even with copper sprays, peach leaf curl was a problem in wet springs. The most heavily affected varieties were Spring Crest, Flavor Crest, Fay Elberta, and Forty Niner; least affected were Red Haven, Gene Elberta, and Nectar (white-fleshed). Peaches need heavy pruning in the dormant season, and the fruit load needs to be thinned to maintain individual fruit size.

\section{Nectarines}

Like the peaches, nectarines were grown on Lovell peach rootstock. Similarly, they need to be pruned heavily and the fruit thinned to achieve good individual fruit size. Nectarines are very susceptible to thrips damage, which can be expected if a spray is not applied at late bloom. All of the nectarine varieties had severe peach leaf curl, more severe than on the peaches. Some trees declined and died after the soil was saturated by El Niño rains in early April, 1998. Royal Giant was not affected by waterlogging damage, though, and was less damaged from thrips, but it did get severe peach leaf curl. All nectarine varieties produced low yields of poor-quality fruit overall and did not appear to be adapted to the foothill study site (table 2).

\section{Plums}

The Santa Rosa plum variety grown on Myrobalan (Myro) 29C rootstock was a consistent producer and seemed well adapted to the site; this same variety was not as productive when grown on Lovell rootstock. Aphids were the main pest problem, causing severe leaf curling symptoms. Aphids were very severe on the Elephant Heart variety, less severe on the Simka variety, and typically not a problem on the Santa Rosa variety. Delayed dormant oil sprays by themselves failed to control the leaf curl plum aphid. Commercial applicators usually use an insecticide other than dormant oil to control aphids where they are a problem. Where plums are grown organically, these insecticides cannot be used. The best practice there is to apply the highest label rate of oil during early bloom in March. You can also release aphid parasitoids. 
Table 1. Fruit and nut harvest timing at the study site

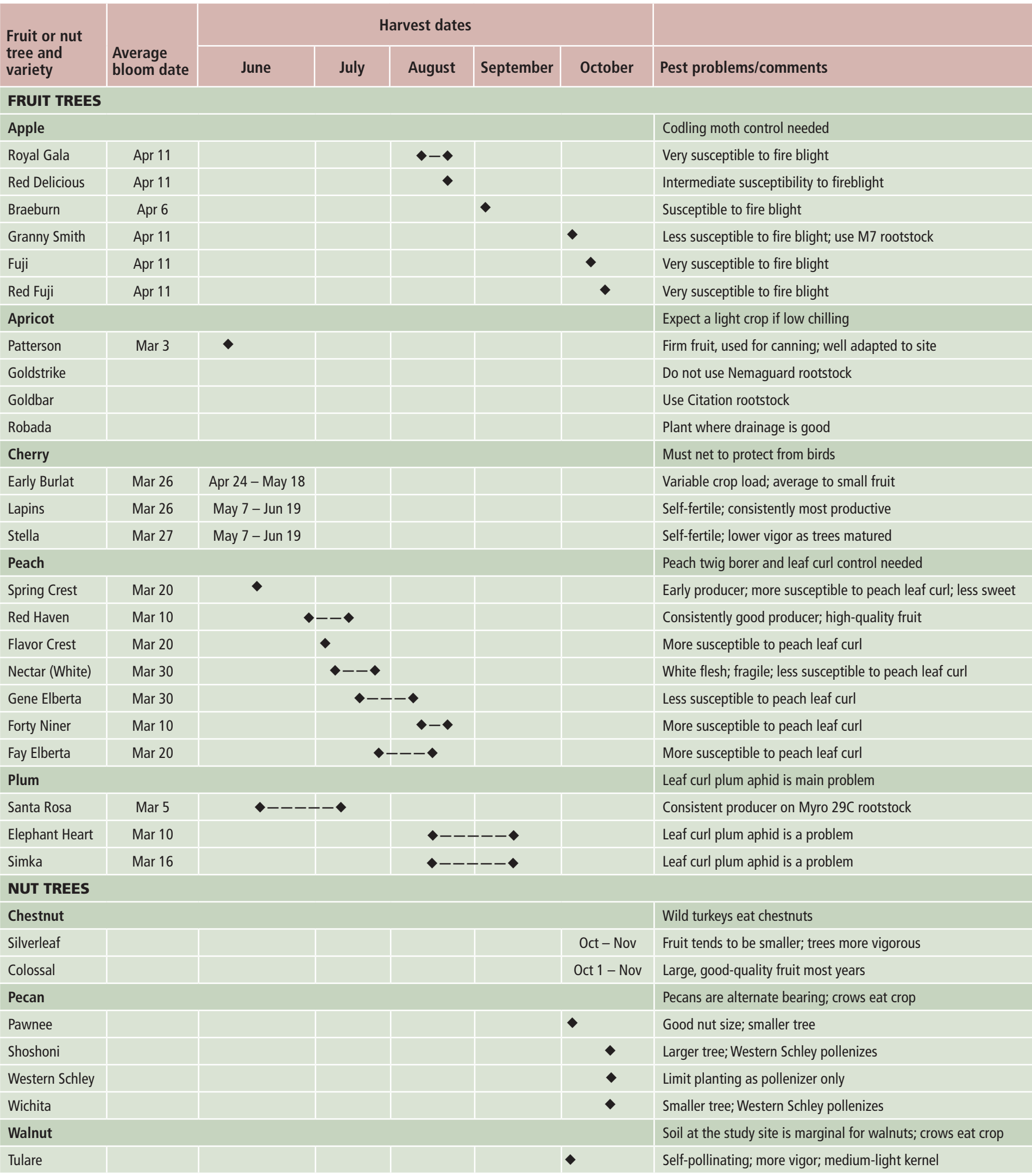


Table 2. Tree crops, varieties, and variety-rootstock combinations not recommended for low-elevation Sierra foothills, based on poor performance at the study site

\begin{tabular}{|l|l|l|l|}
\hline Tree crop & Variety & Rootstock & Reason \\
\hline Apple & Arkansas Black & M111 (only one tested) & Poor growth and fruit quality \\
\hline Apple & Gala & M111 and M7 & Poor growth \\
\hline Apple & Granny Smith & M111 & Poor growth \\
\hline Apple & Spitzenberg & M7 (only one tested) & Poor growth \\
\hline Apricot & Blenheim (Royal) & Marianna 2624 & Bacterial canker and Eutypa diseases \\
\hline Nectarine & $\begin{array}{l}\text { Summergrand, Fantasia, Flavortop, } \\
\text { Red Gold, Royal Giant }\end{array}$ & Lovell & $\begin{array}{l}\text { Poor production and fruit quality, peach leaf curl, thrips, } \\
\text { waterlogging damage (Red Gold) }\end{array}$ \\
\hline Plum & Elephant Heart (EH) & Lovell & Leaf curl plum aphid, unless able to control it \\
\hline Plum & Kelsey & Lovell & Very poor growth; leaf curl plum aphid \\
\hline Plum & Simka & Myro 29-C & Leaf curl plum aphid, unless able to control it; less vigor than EH \\
\hline Walnut & Cisco & Paradox & Poor growth, declined most quickly; pollenizer for Chandler \\
\hline Walnut & Chandler & Paradox & Declined within 10 years \\
\hline
\end{tabular}

\section{Cherries}

The cherries were all grown on size-controlling Colt rootstock. The fruiting spurs on cherries remain productive for 10 to 12 years, so they rarely need pruning. Overall, the cherries in the study performed well. The Lapins variety was consistently the most productive. It is a self-fertile variety, as is the Stella variety, which did not perform as well as the Lapins variety. Early Burlat, which is not self-fertile, needs another cherry variety for pollination. It tended to have light crops, more blossom brown rot (Monilinia fructicola or laxa) in wet springs, and more bird damage. Netting is commonly used to keep birds from damaging cherry crops.

\section{Walnuts}

Walnut trees are deep-rooted, so for the study we used Paradox rootstock, which is noted for its vigor and better adaptation to marginal soils. This rootstock is susceptible to crown gall disease, however, which was visible on one tree. Although initial tree growth was vigorous, all varieties showed reduced vigor within eight years on these heavier, shallow soils. The variety Tulare, which has more vigor, grew better than the Chandler variety. However, two declining Tulare trees and one Cisco (pollenizer) tree were removed after 11 years. In study site's soil, mature walnut trees needed pruning at least every other year to stimulate growth. The walnuts suffered little pest damage other than crows eating the crop. Even with low pest damage levels, though, the vigor and productivity of walnut trees progressively declined under foothill soil conditions.

\section{Pecans}

The pecan trees were slow to establish at the study site. Pecan trees require zinc sulfate sprays during the establishment period, and you need to continue to monitor zinc levels on mature trees. Pecans require little pruning except as necessary to keep the limbs from hanging down from the weight of the crop. Pecans are alternate-year bearing, so expect a heavier crop year to be followed by a light crop. Western Schley, a pollenizer for Wichita and Shoshoni, should be included in foothill plantings even though it was a low producer at the study site. Pawnee was a more consistent producer early on than in the later years. It is a smaller tree than Shoshoni, a trait that can be desirable for a backyard orchard. Crows may eat the nuts before harvest, so you will want to net at least the lower limbs to prevent damage. No aphid damage was observed.

\section{Chestnuts}

The two chestnut varieties in the study, Silverleaf and Colossal, and one Colossal seedling pollenizer tree never grew very large on our foothill soil. Chestnuts are grown on a seedling rootstock. The Silverleaf trees were more vigorous and tended to produce heavy crops with generally smaller fruit than the Colossal trees. Chestnuts are sensitive to poor drainage; one Silverleaf tree suddenly collapsed in 2002 from what appeared to be root and crown rot. Wild turkeys and crows may eat the crop.

\section{Hazelnuts}

Three own-rooted hazelnut varieties-Barcelona, Casina, and Butler-were planted in 2003, replacing walnut trees. These were trained as multi-trunk bushes rather than as trees. At three years of age, the bushes were growing well but they had not yet cropped when the study ended. (Hazelnut trees do not generally bear a commercial crop until their fourth year.) 


\section{Cultural and Pest Management INFORMATION}

The Fruit and Nut Center at UC Davis (http:// fruitsandnuts.ucdavis.edu) provides information on pruning, fertilization, and other practices for several tree crops. At the home page, click on "The Backyard Orchard." Explanations and information on chill hours are available from the home page if you click on "Weather-Related Models." The average annual chill hours accumulated for the years 2003 to 2009 at the demonstration orchard was 743 hours (from November 1 through February, when temperatures were between $32^{\circ}$ and $45^{\circ} \mathrm{F}$ at the Browns Valley CIMIS weather station).

Information on scheduling irrigations based on weather monitoring is available at the California Irrigation Management Information System (CIMIS) website (http://www.cimis.water.ca.gov). You'll need to register the first time you use CIMIS, but access to the data is always free. Click on the info center and data tabs and you'll find the information you need to schedule irrigations based on historical or real-time evapotranspiration values (ET) and crop coefficients $\left(\mathrm{K}_{\mathrm{c}}\right)$. To obtain data, you have to select a specific
CIMIS weather station. The Browns Valley CIMIS weather station at the Sierra Foothill Research and Extension Center is station \#84. Select the weather station that has weather conditions most similar to those at your orchard site.

The UC Integrated Pest Management (IPM) website for the backyard and home orchard (http://ipm.ucdavis.edu/PMG/GARDEN/fruit.html) provides information for managing major and minor pests of fruit and nut trees and cultural information on pruning, fertilizing, and more. Degree-days to help you determine spray timing for specific temperature-driven insect pests such as codling moth and peach twig borer can be calculated using the information at the "Degree-days" link on the IPM home page (http://ipm.ucdavis.edu).

\section{ACKNOWLEDGMENTS}

The demonstration orchard used in this study was made possible by the generous contributions of trees from Fowler Nurseries, Inc., Sierra Gold Nurseries, Linwood Nursery, Stuke Nursery, and Dave Wilson Nursery, and by the irrigation system provided by Circle R Irrigation.

\section{FOR MORE INFORMATION}

You will find related information in these titles and in other publications, slide sets, CD-ROMs, and videos from UC ANR:

California Master Gardener Handbook, Publication 3382

Drip Irigation in the Home Landscape, Publication 21579

The Home Orchard, Publication 3485

Tree Fruit Pest Identification and Monitoring Cards, Publication 3426

To order these products, visit our online catalog at

http://anrcatalog.ucdavis.edu. You can also place orders by mail, phone, or FAX, or request a printed catalog of publications, slide sets, CD-ROMs, and videos from

\section{University of California}

Agriculture and Natural Resources

Communication Services

6701 San Pablo Avenue, 2nd Floor

Oakland, California 94608-1239

Telephone: (800) 994-8849 or (510) 642-2431, FAX: (510) 643-5470

e-mail inquiries: danrcs@ucdavis.edu

An electronic version of this publication is available on the ANR Communication Services website at http://anrcatalog.ucdavis.edu.

Publication 8396

ISBN-13: 978-1-60107-671-7

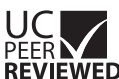

This publication has been anonymously peer reviewed for technical accuracy by University of California scientists and other qualified professionals. This review process was managed by the ANR Associate Editor for Pomology, Viticulture, and Subtropical Horticulture.

(C) 2009 by The Regents of the University of California Agriculture and Natural Resources.

All rights reserved.
The University of California prohibits discrimination or harassment of any person on the basis of race, color, national origin, religion, sex, gender identity, pregnancy (including childbirth, and medical conditions related to pregnancy or childbirth), physical or mental disability, medical condition (cancer-related or genetic characteristics), ancestry, marital status, age, sexual orientation, citizenship, or service in the uniformed services (as defined by the Uniformed Services Employment and Reemployment Rights Act of 1994: service in the uniformed services includes membership, application for membership, performance of service, application for service, or obligation for service in the uniformed services) in any of its programs or activities.

University policy also prohibits reprisal or retaliation against any person in any of its programs or activities for making a complaint of discrimination or sexual harassment or for using or participating in the investigation or resolution process of any such complaint.

University policy is intended to be consistent with the provisions of applicable State and Federal laws.

Inquiries regarding the University's nondiscrimination policies may be directed to the Affirmative Action/Equal Opportunity Director, University of California, Agriculture and Natural Resources, 1111 Franklin Street, $6^{\text {th }}$ Floor, Oakland, CA 94607, (510) 987-0096. For information about obtaining this publication, call (800) 994-8849. For downloading information, call (530) 754-3927.

web-11/09-WJC/CR 